\title{
Analisis Literasi Digital Mahasiswa Calon Guru Biologi Melalui Proyek Video Amatir Berbasis Potensi Lokal pada Mata Kuliah Ekologi Tumbuhan
}

\author{
Adi Pasah Kahar \\ Pendidikan Biologi, FKIP, Universitas Muhammadiyah Pontianak, Indonesia
}

Pengiriman: 2 Maret 2018; Diterima: 12 April 2018; Publikasi: Maret 2018

\begin{abstract}
The purpose of this study to know the degree of digital literacy of the students teacher towards video project based on local potency in West Borneo. This study uses descriptive qualitative methods. The subjects of the study was taken by using systematic sampling technic. The technic of collecting data uses the indirect communication, observation, and direct communication. Collecting data uses observation sheet, and dialogue sheet. The technic of data analysis uses descriptive statistical analysis. The result of the study shows that the degree of the digital literacy of the students is high. It means that the students can use computer $(71 \%)$ and the ability to use internet (63\%). The degree of the digital literacy of the students is moderate. It means that the percentage of the students who can use internet to find biology information only (61\%), the percentage of reading biology books via internet only (58\%), and to spread and to criticize biological information (58\%). The degree of digital literacy is regarded low. This can be seen from having social net to inform about biology $(8 \%)$ and to distinguish the sources eithen valid or invalid (8\%), the ability to find information about biology (3\%), and the ability to produce media to spread information of biology (5\%). Based on the result get, can be concluded that the degree of digital literacy of students are medium level.
\end{abstract}

Keywords: Local Potency, Digital Literacy, Video,

\begin{abstract}
ABSTRAK: Penelitian ini bertujuan untuk menganalisis literasi digital melalui proyek video amatir yang bersumber dari potensi lokal di daerah Kalimantan Barat. Penelitian ini menggunakan metode kualitatif deskriptif dengan subjek penelitian adalah mahasiswa calon guru semester 4 program studi pendidikan biologi. Hasil penelitian menunjukkan bahwa literasi digital. Teknik pengumpulan data menggunakan komunikasi tidak langsung, observasi, dan komunikasi langsung. Pengumpulan data menggunakan lembar angket, lembar observasi, dan lembar wawancara. Teknik analisis data yang digunakan adalah analisis statistik deskriptif. Hasil penelitian menunjukkan bahwa tingkat literasi digital mahasiswa tergolong tinggi pada indikator kemampuan menggunakan komputer (71\%) dan kemampuan menggunakan internet (63\%). Tingkat literasi digital mahasiswa tergolong sedang pada indikator persentase menggunakan internet untuk mencari informasi potensi lokal (61\%), persentase membaca buku melalui internet (58\%), dan menyebarkan dan mengkritik informasi (58\%). Tingkat literasi digital mahasiswa tergolong sangat rendah pada indikator memiliki akun jejaring sosial untuk berbagi informasi potensi lokal (8\%), indikator kemampuan membedakan sumber yang valid atau tidak valid (8\%), kemampuan mencari informasi potensi lokal (3\%), dan kemampuan memproduksi media untuk berbagi informasi potensi lokal (5\%). Berdasarkan hasil yang diperoleh dapat disimpulkan bahwa tingkat literasi digital mahasiswa calon guru tergolong tingkat sedang.
\end{abstract}

Kata Kunci: Potensi Lokal, Literasi Digital, Video Amatir

*Penulis Korespondensi:

Alamat surel: adipasahkahar@unmuhpnk.ac.id 


\section{PENDAHULUAN}

Kalimantan Barat termasuk salah satu provinsi di Indonesia yang memiliki keanekargaman hayati yang cukup tinggi dengan potensi lokal yang beraneka ragam dari SDA, wisata, kuliner, dan tradisi. Informasi potensi lokal Kalimantan Barat jarang sekali dijumpai baik dalam bentuk media cetak ataupun media elektronik. Sehingga hampir sebagian besar mahasiswa calon guru tidak mengetahui potensi lokal yang ada di daerahnya sendiri. Kondisi ini menciptakan ketidakpedulian dan ketidakperhatian terhadap daerahnya.

Ketidaktahuan mahasiswa calon guru biologi terhadap potensi lokal di daerahnya akan berakibat pada proses pembelajaran biologi di kelas. Pembelajaran biologi menuntut adanya relevansi antara teori yang ada dengan contoh kehidupan sehari-hari. Relevansi proses pembelajaran di kelas dengan fenomena dan karakteristik khas yang ada di daerah mereka dalam hal ini potensi lokal Kalimantan Barat diharapkan dapat mendorong terbentuknya pembelajaran biologi yang kontekstual ketika mereka menjadi guru dan mengajarkan materi biologi nantinya.

Salah satu upaya yang dapat dilakukan adalah dengan mengenalkan lebih jauh keunggulan lokal kepada pesreta didik sedini mungkin. Dengan demikian upaya untuk mengintegrasikan muatan nilai keunggulan lokal ke dalam jalur pendidikan perlu dilakukan (Yokhebed, dkk, 2016).

Mengacu pada hasil penelitian Susilo (2015) bahwa potensi lokal yang belum dimanfaatkan secara optimal dalam kegiatan pembelajaran biologi, disebabkan dosen-dosen biologi belum banyak berkarya untuk mengembangkan materi biologi yang berbasis potensi lokal/karakteristik yang ada di daerah setempat. Dosen masih banyak menggunakan sumber belajar yang sudah tersedia di pasaran yang tidak cocok dengan kondisi sekolah maupun karakteristik peserta didik, sehingga masih harus dilakukan penyesuaianpenyesuaian.

Di sisi lain perkembangan teknologi informasi sangat pesat dan tidak dapat dibendung lagi. Perkembangan teknologi informasi dan komunikasi (TIK) telah memberi pengaruh besar dalam seluruh aspek kehidupan, termasuk dunia pendidikan (Budiana, 2015). Berkembangnya TIK tersebut memberikan dampak positif maupun dampak negatif. Agar pemanfaatan TIK dalam pembelajaran biologi lebih optimal dan dilaksanakan dengan baik dan benar maka harus diimbangi dengan literasi digital. Literasi digital merupakan kemampuan menggunakan teknologi digital untuk memahami, mengevaluasi, menggunakan dan menciptakan informasi (Sokowati, 2014).

Pelajar yang menggunakan internet hanya sebesar 8,3 juta $(6,3 \%)$ dengan menggunakan perangkat mobile, komputer atau keduanya. Namun, penggunaan internet di Kalimantan hanya sebesar 7,7 juta $(5,8 \%)$. Jenis konten yang diakses oleh pengguna internet dapat dilihat pada Tabel 1 .

Tabel 1 Penggunaan Internet

\begin{tabular}{lll}
\hline $\begin{array}{l}\text { Jenis Konten } \\
\text { yang Diakses }\end{array}$ & $\begin{array}{l}\text { Jumlah } \\
\text { Penduduk }\end{array}$ & \% \\
\hline Media Sosial & 129,2 juta & $97,4 \%$ \\
Hiburan & 128,4 juta & $96,8 \%$ \\
Berita & 127,9 juta & $96,4 \%$ \\
Pendidikan & $\mathbf{1 2 4 , 4}$ juta & $\mathbf{9 3 , 8 \%}$ \\
Komersial & 123,5 juta & $93,1 \%$ \\
Layanan Publik & 121,5 juta & $91,6 \%$ \\
\hline
\end{tabular}

\section{Sumber: APJII, 2016}

Herlina (2015) menjelaskan bahwa literasi digital dalam pembelajaran biologi sangat penting. Literasi digital melibatkan aksi digital yang terikat dengan pembelajaran biologi. Selain itu, literasi digital juga melibatkan kemampuan menggunakan pengetahuan, sikap, teknik dan kualitas personal untuk menyelesaikan permasalahan dalam pembelajaran biologi. Berdasarkan uraian 
tersebut, maka perlu dilakukan analisis terkait literasi digital mahasiswa calon guru biologi.

\section{METODE PENELITIAN}

Penelitian ini adalah penelitian deskriptif dengan pendekatan kualitatif. Subjek penelitian diambil menggunakan teknik sampling sistematis yaitu mahasiswa semester 4 program studi pendidikan biologi berjumlah 37 siswa. Teknik pengumpul data yang digunakan adalah komunikasi tidak langsung, observasi, dan komunikasi langsung. Alat pengumpul data yang digunakan adalah lembar angket, lembar observasi, dan pedoman wawancara. Setelah data direduksi, maka langkah selanjutnya adalah menyajikan data. Data disajikan dalam kalimat naratif, tabel dan grafik. Melalui penyajian data tersebut, data akan semakin mudah untuk dipahami. Triangulasi yang digunakan dalam penelitian ini adalah triangulasi sumber. Dalam penelitian ini, peneliti mengecek data yang diperoleh dari dosen, tim observer dan mahasiswa yang menjadi subjek penelitian. Data dari berbagai sumber tersebut dibandingkan dan dianalisis sehingga menghasilkan suatu kesimpulan.

\section{HASIL DAN PEMBAHASAN}

Literasi digital merupakan kemampuan menggunakan teknologi digital untuk memahami, mengevaluasi, menggunakan dan menciptakan informasi (Sokowati, 2014:61). Tingkat literasi digital dapat diketahui melalui beberapa indicator dan hasilnya dapat dilihat pada Tabel 1.

a. Persentase Menggunakan Internet untuk Mencari Informasi Potensi Lokal Kalimantan Barat

Berdasarkan hasil angket diketahui bahwa mahasiswa tergolong tingkat sedang (61\%) dalam hal persentase menggunakan internet untuk mencari informasi potensi lokal Kalimantan Barat. Meskipun rata-rata tergolong sedang, ternyata ada enam mahasiswa yang tergolong rendah. Setelah diwawancara, mereka memang tidak pernah menggunakan internet untuk mencari informasi. Penggunaan internet banyak mereka habiskan untuk aktivitas lain, seperti bermain media sosial, game, dan lain sebagainya.

Tabel 1. Hasil Angket Literasi Digital Mahasiswa

\begin{tabular}{|c|c|c|c|}
\hline No. & Indikator & Persentase & Tingkat \\
\hline 1. & $\begin{array}{l}\text { Persentase } \\
\text { menggunakan } \\
\text { internet untuk } \\
\text { mencari informasi } \\
\text { biologi }\end{array}$ & $61 \%$ & Sedang \\
\hline 2. & $\begin{array}{l}\text { Persentase } \\
\text { membaca buku } \\
\text { biologi melalui } \\
\text { internet }\end{array}$ & $58 \%$ & Sedang \\
\hline 3. & $\begin{array}{l}\text { Kemampuan } \\
\text { mencari informasi } \\
\text { biologi }\end{array}$ & $53 \%$ & Sedang \\
\hline 4. & $\begin{array}{l}\text { Kemampuan } \\
\text { membedakan } \\
\text { sumber yang valid } \\
\text { atau tidak valid }\end{array}$ & $56 \%$ & Sedang \\
\hline 5. & $\begin{array}{l}\text { Menyebarkan dan } \\
\text { mengkritik } \\
\text { informasi biologi }\end{array}$ & $58 \%$ & Sedang \\
\hline 6. & $\begin{array}{l}\text { Memiliki akun } \\
\text { jejaring } \\
\text { untuk } \text { sosial } \\
\text { informasi biologi }\end{array}$ & $54 \%$ & Sedang \\
\hline 7. & $\begin{array}{l}\text { Kemampuan } \\
\text { memproduksi } \\
\text { media untuk } \\
\text { berbagi informasi } \\
\text { biologi }\end{array}$ & $55 \%$ & Sedang \\
\hline
\end{tabular}

Berdasarkan hasil dokumentasi, rata-rata hasil belajar mahasiswa pada mata kuliah Ekologi Tumbuhan biologi hanya 77,46 . Nilai yang diperoleh mahasiswa tersebut dapat ditingkatkan melalui pembelajaran yang menggunakan media digital. Hal ini diperkuat dari hasil penelitian oleh Umam (2013) yang menunjukkan bahwa aktivitas dan hasil belajar siswa yang mengikuti pembelajaran dengan media digital lebih baik dan masuk dalam 
kriteria sangat baik daripada aktivitas dan hasil belajar siswa pada kelas dengan pembelajaran tanpa media digital.

\section{b. Persentase Membaca Buku Biologi Melalui Internet}

Hasil angket pada indikator persentase membaca buku biologi melalui internet menunjukkan bahwa mahasiswa tergolong tingkat sedang (58\%). Berdasarkan hasil wawancara dengan mahasiswa, materi yang mereka baca melalui internet adalah materi yang ada pada blog orang lain. Hanya satu mahasiswa yang pernah membaca materi biologi menggunakan e-book. Namun, setelah ditanya seberapa sering membaca buku biologi melalui internet, mahasiswa menjawab jarang sekali. Terdapat tujuh mahasiswa yang tergolong rendah. Setelah diwawancara, mahasiswa tersebut memang tidak pernah membaca buku biologi melalui internet. Mereka membaca materi biologi pada buku pegangan atau pun buku paket yang ada di perpustakaan. Jika dikaitkan dengan indikator kemampuan mencari informasi biologi, terdapat perbedaan yang sangat mencolok. Tingkat literasi digital mahasiswa pada indikator kemampuan mencari informasi biologi adalah sangat rendah (3\%). Hal ini dikarenakan mahasiswa membaca materi biologi yang terdapat pada blog. Sedangkan pada e-book hanya satu mahasiswa. Salah satu syarat yang harus dimiliki mahasiswa jika memiliki kemampuan mencari informasi biologi adalah dapat memanfaatkan e-book untuk mencari informasi biologi dan tidak menggunakan blog karena menurut Maharani (2013) kebanyakan situs, terutama blog tidak memiliki pengarang serta sumber yang jelas.

Materi biologi akan lebih menarik dan mudah dipelajari mahasiswa jika dikemas dalam format digital. Selain memudahkan mahasiswa memahami materi, juga berguna untuk meningkatkan aktivitas belajar mahasiswa dan memberikan kontribusi yang positif terhadap hasil belajarnya (Jayawardana, 2017). Selain itu, internet telah menjadi kebutuhan mahasiswa setiap hari yang diakses melalui laptop, komputer, handphone, ataupun alat lainnya (Susena, 2014). Oleh karena itu, hal tersebut dapat dijadikan momentum bagi dosen untuk memanfaatkan kemajuan teknologi dalam pembelajaran biologi.

Tabel 2. Hasil Observasi Literasi Digital Mahasiswa

\begin{tabular}{|c|c|c|c|}
\hline No. & Indikator & Persentase & Tingkat \\
\hline 1. & $\begin{array}{l}\text { Kemampuan } \\
\text { menggunakan } \\
\text { computer }\end{array}$ & $71 \%$ & Tinggi \\
\hline 2. & $\begin{array}{l}\text { Kemampuan } \\
\text { menggunakan } \\
\text { internet }\end{array}$ & $63 \%$ & Tinggi \\
\hline 3. & $\begin{array}{l}\text { Kemampuan } \\
\text { mencari } \\
\text { informasi } \\
\text { biologi }\end{array}$ & $3 \%$ & $\begin{array}{l}\text { Sangat } \\
\text { Rendah }\end{array}$ \\
\hline 4. & $\begin{array}{l}\text { Kemampuan } \\
\text { membedakan } \\
\text { sumber yang } \\
\text { valid atau tidak } \\
\text { valid }\end{array}$ & $8 \%$ & $\begin{array}{l}\text { Sangat } \\
\text { Rendah }\end{array}$ \\
\hline 5. & $\begin{array}{l}\text { Memiliki akun } \\
\text { jejaring sosial } \\
\text { untuk berbagi } \\
\text { informasi } \\
\text { biologi }\end{array}$ & $8 \%$ & $\begin{array}{l}\text { Sangat } \\
\text { Rendah }\end{array}$ \\
\hline 6. & $\begin{array}{l}\text { Kemampuan } \\
\text { memproduksi } \\
\text { media untuk } \\
\text { berbagi } \\
\text { informasi } \\
\text { biologi }\end{array}$ & $5 \%$ & $\begin{array}{l}\text { Sangat } \\
\text { Rendah }\end{array}$ \\
\hline
\end{tabular}

c. Menyebarkan dan Mengkritik
Informasi Biologi

Hasil angket pada indikator menyebarkan dan mengkritik informasi biologi menunjukkan bahwa mahasiswa tergolong tingkat sedang (58\%). Namun, terdapat 14 mahasiswa yang tergolong rendah. Setelah diwawancara, mahasiswa memang menerima begitu saja informasi biologi yang ia dapatkan dari 
internet. Setelah mendapatkan informasi yang mereka butuhkan, mereka tidak menyebarkan informasi tersebut ke teman atau orang lain. Seharusnya, menurut Sutartono (2015) jika ada hal baru, siswa tidak akan ragu-ragu mempelajarinya untuk kemudian menanggapi dengan kritis dan selektif. Dari informasi baru yang diperolehnya, mahasiswa dapat menolak pendapat yang salah atau mungkin membahayakan baik bagi dirinya, orang lain, maupun lingkungan.

\section{d. Kemampuan Menggunakan Komputer}

Berdasarkan hasil observasi diketahui bahwa mahasiswa sudah tergolong tingkat tinggi (71\%) dalam hal kemampuan menggunakan komputer. Namun, terdapat dua mahasiswa yang tidak bisa menggunakan komputer. Bagian yang mereka tidak bisa adalah menunjukkan port USB, menghidupkan dan mematikan komputer dengan langkah yang berurutan, mengidentifikasi ikon internet browser, control panel dan recycle bin. Setelah diwawancara, siswa lupa dan memang tidak mengetahui bagian tersebut.

Mahasiswa yang memiliki kemampuan tersebut dapat memanfaatkan komputer dalam hal pembelajaran atau sekolah. Komputer/laptop dapat digunakan untuk menyimpan data-data atau informasi yang dimilikinya (student data collection), perangkat untuk melakukan penilaian (student assessment), sarana penelitian (student research), memberikan pengalaman secara virtual (simulated experiences), melakukan analisis secara digital (analysis of digitized performanced), dan latihan ujian (learning exercises) (Jayawardana, 2017). Selain itu, komputer juga dapat dijadikan sebagai sarana permainan yang tentu saja permainan yang berkaitan dengan pelajaran biologi (Husain, 2014).
Tabel 3 Rekapitulasi Tingkat Literasi Digital Mahasiswa

\begin{tabular}{|c|c|c|c|}
\hline No & Indikator & $\%$ & Tingkat \\
\hline 1 & $\begin{array}{l}\text { Persentase } \\
\text { menggunakan } \\
\text { internet untuk } \\
\text { mencari informasi } \\
\text { biologi }\end{array}$ & $61 \%$ & Sedang \\
\hline 2 & $\begin{array}{l}\text { Persentase } \\
\text { membaca } \\
\text { biologi } \\
\text { internet }\end{array}$ & $58 \%$ & Sedang \\
\hline 3 & $\begin{array}{l}\text { Menyebarkan dan } \\
\text { mengkritik } \\
\text { informasi biologi }\end{array}$ & $58 \%$ & Sedang \\
\hline 4 & $\begin{array}{l}\text { Kemampuan } \\
\text { menggunakan } \\
\text { komputer }\end{array}$ & $71 \%$ & Tinggi \\
\hline 5 & $\begin{array}{l}\text { Kemampuan } \\
\text { menggunakan } \\
\text { internet }\end{array}$ & $63 \%$ & Tinggi \\
\hline 6 & $\begin{array}{lr}\text { Memiliki } & \text { akun } \\
\text { jejaring } & \text { sosial } \\
\text { untuk } & \text { berbagi } \\
\text { informasi biologi }\end{array}$ & $8 \%$ & $\begin{array}{l}\text { Sangat } \\
\text { Rendah }\end{array}$ \\
\hline 7 & $\begin{array}{l}\text { Kemampuan } \\
\text { membedakan } \\
\text { sumber yang valid } \\
\text { atau tidak valid }\end{array}$ & $8 \%$ & $\begin{array}{l}\text { Sangat } \\
\text { Rendah }\end{array}$ \\
\hline 8 & $\begin{array}{l}\text { Kemampuan } \\
\text { mencari } \\
\text { informasi biologi }\end{array}$ & $3 \%$ & $\begin{array}{l}\text { Sangat } \\
\text { Rendah }\end{array}$ \\
\hline 9 & $\begin{array}{l}\text { Kemampuan } \\
\text { memproduksi } \\
\text { media untuk } \\
\text { berbagi informasi } \\
\text { biologi }\end{array}$ & $5 \%$ & $\begin{array}{l}\text { Sangat } \\
\text { Rendah }\end{array}$ \\
\hline
\end{tabular}

\section{e. Kemampuan Menggunakan Internet}

Hasil observasi pada indikator ini diketahui bahwa mahasiswa sudah tergolong tingkat tinggi (63\%). Namun, terdapat tiga mahasiswa yang tidak mampu menggunakan internet seperti mengidentifikasi dan mengoperasikan internet explorer, chrome, bing, google scholar, dan email. Setelah diwawancara, mahasiswa memang tidak mengetahui dengan alasan asing bagi mereka. Mereka juga lupa 
cara membuka maupun mengirim email karena sudah lama tidak diajarkan.

Kemampuan mahasiswa yang tinggi dalam menggunakan internet akan lebih baik jika dimanfaatkan untuk keperluan belajar, khususnya pembelajaran biologi. Menurut Jayawardana (2017), suasana pembelajaran yang menggunakan internet akan membuat siswa lebih aktif dalam proses belajarnya, karena siswa dapat mencari materi dengan usaha dan inisiatif sendiri.

\section{f. Memiliki Akun Jejaring Sosial untuk} Berbagi Informasi Potensi Lokal

Berdasarkan hasil angket pada indikator memiliki akun jejaring sosial untuk berbagi informasi berada pada tingkat sedang (54\%). Sedangkan berdasarkan hasil observasi berada pada tingkat sangat rendah $(8 \%)$. Hasil dari kedua alat pengumpul data tersebut menghasilkan tingkat yang sangat berbeda. Setelah diwawancara, semua mahasiswa memang memiliki akun jejaring sosial, namun akun tersebut rata-rata tidak digunakan mahasiswa untuk berbagi informasi. Akun tersebut sebatas digunakan untuk menanyakan tentang tugas dan mengirimkan materi melalui pesan facebook dan whatsapp ketika tugas kelompok. Selain itu, perbedaan hasil penelitian juga dikarenakan kelemahan dari angket adalah dapat terjadinya informasi yang bias (Pujihastuti, 2010). Menurut Nuryani (2014), bermain media sosial dapat membuang waktu mereka. Waktu yang seharusnya digunakan untuk belajar, malah digunakan untuk bermain di dunia maya. Hal ini akan mengakibatkan penurunan prestasi yang dimiliki remaja tersebut.

\section{g. Kemampuan Membedakan Sumber yang Valid atau Tidak Valid}

Berdasarkan hasil angket pada indikator memiliki kemampuan untuk membedakan sumber yang valid atau tidak valid berada pada tingkat sedang (56\%). Sedangkan berdasarkan hasil observasi berada pada tingkat sangat rendah $(8 \%)$. Hasil dari kedua alat pengumpul data tersebut menghasilkan tingkat yang sangat berbeda. Setelah diwawancara, sebagian mahasiswa memang sudah pernah mendengar istilah sumber yang valid dan tidak valid. Namun, setelah ditanya kriteria sumber yang valid, mahasiswa menjawab tidak tahu. Selain itu, perbedaan hasil penelitian juga dikarenakan kelemahan dari angket adalah dapat terjadinya informasi yang bias (Pujihastuti, 2010).

Hasil rekapitulasi angket, observasi, dan wawancara menunjukkan bahwa mahasiswa memang tergolong tingkat sangat rendah dalam hal membedakan sumber yang valid atau tidak valid. Mahasiswa menggunakan semua sumber seperti blog pada google untuk memperoleh informasi tentang materi biologi. Kebanyakan situs, terutama blog tidak memiliki pengarang serta sumber yang jelas (Maharani, 2013). Menurut Utami (2007), mahasiswa seharusnya dapat berpikir kritis dan bisa membedakan antara fakta dan opini, antara isu, atau yang umum disebut sebagai hoax, dengan berita sebenarnya. Karena menurut Taufiq (2012), jika tidak bisa membedakan sumber informasi yang jelas dan akurat, besar kemungkinan terjadinya kesalahan dalam memahami konsep materi.

\section{h. Kemampuan Memproduksi Media untuk Berbagi Informasi Potensi Lokal}

Berdasarkan hasil angket pada indikator kemampuan memproduksi media untuk berbagi informasi potensi lokal berada pada tingkat sedang (55\%). Sedangkan berdasarkan hasil observasi berada pada tingkat sangat rendah $(5 \%)$. Hasil dari kedua alat pengumpul data tersebut menghasilkan tingkat yang sangat berbeda. Setelah diwawancara, diketahui bahwa dua mahasiswa pernah membuat blog. Namun hanya digunakan satu kali untuk mengunggah materi keanekaragaman hayati dan tidak pernah digunakan lagi karena alasan lupa password. 
Selain itu, perbedaan hasil penelitian juga dikarenakan kelemahan dari angket adalah dapat terjadinya informasi yang bias (Pujihastuti, 2010).

Hasil rekapitulasi angket, observasi, dan wawancara menunjukkan bahwa mahasiswa memang tergolong tingkat sangat rendah. Seharusnya, internet yang memudahkan akses informasi, mahasiswa dapat menambah wawasan, bersosialisasi, dan berinteraksi dalam jangkauan yang luas sehingga memperluas pergaulan dan terpacu untuk mengekspresikan kreativitas yang mereka miliki kepada orang lain (Siyamitri, 2015). Hal ini diperkuat dari hasil penelitian Sambada (2012) bahwa terdapat pengaruh positif antara kreativitas mahasiswa terhadap kemampuan mahasiswa dalam memecahkan masalah pembelajaran.

\section{KESIMPULAN DAN SARAN}

Tingkat literasi digital mahasiswa pada indikator persentase menggunakan internet untuk mencari informasi potensi lokal tergolong tingkat sedang $(61 \%)$. Indikator persentase membaca buku biologi melalui internet tergolong tingkat sedang (58\%). Indikator menyebarkan dan mengkritik informasi tergolong tingkat sedang (58\%). Indikator kemampuan menggunakan komputer tergolong tingkat tinggi (71\%). Indikator kemampuan menggunakan internet tergolong tingkat tinggi (63\%). Indikator memiliki akun jejaring sosial untuk berbagi informasi tergolong tingkat sangat rendah (8\%). Indikator kemampuan membedakan sumber yang valid atau tidak valid tergolong tingkat sangat rendah $(8 \%)$. Indikator kemampuan mencari informasi biologi tergolong tingkat sangat rendah $(3 \%)$. Indikator kemampuan memproduksi media untuk berbagi informasi biologi tergolong tingkat sangat rendah $(5 \%)$

\section{DAFTAR PUSTAKA}

Asosiasi Penyelenggara Jasa Internet Indonesia (APJII). Penetrasi \& Perilaku Pengguna Internet Indonesia. 2016.
Budiana, H.R., Sjafirah, N.A., \& Bakti, I. Pemanfaatan Teknologi Informasi dan Komunikasi dalam Pembelajaran Bagi Para Guru SMPN 2 Kawali Desa Citeureup Kabupaten Ciamis. Jurnal Aplikasi Ipteks Untuk Masyarakat. 4(1), 2015, 59.

Herlina, D., Membangun Karakter Bangsa Melalui Literasi Digital. Prosiding Seminar Nasional Kontribusi IlmuIlmu Sosial dalam Percepatan Pembangunan Indonesia Bermartabat. 2015. Yogyakarta: UNY.

Husain, C. Pemanfaatan Teknologi Informasi dan Komunikasi dalam Pembelajaran di SMA Muhammadiyah Tarakan. Jurnal Kebijakan dan Pengembangan Pendidikan. 2014. 2(2): 186-188.

Jayawardana, H.B.A. Paradigma Pembelajaran Biologi di Era Digital. Jurnal Bioedukatika. 2017. V(1): 13-15.

Maharani, S. \& Ardoni. Kredibilitas Informasi Bidang Kesehatan yang Diperoleh Mahasiswa Fakultas Kedokteran Universitas Andalas dari Internet. Jurnal Ilmu Informasi Perpustakaan dan Kearsipan.2013. 2(1): 195.

Sokowati, M.E. Demokrasi dalam Ruang Virtual; Dari Literasi Digital Menuju Partisipasi Publik. 2014. Universitas Muhammadiyah Yogyakarta: Iski.

Nuryani, E. Hubungan Intensitas Mengakses Facebook dengan Motivasi Belajar Siswa SMA Negeri 2 Tenggarong Seberang. E-journal Ilmu Komunikasi. 2014. 2(3): 179.

Pujihastuti, I. Prinsip Penulisan Kuesioner Penelitian. Jurnal Agribisnis dan Pengembangan Wilayah. 2010. 2(1): 50.

Susilo, MJ., Identifikasi Tumbuhan Berbiji (Spermatophyta) Sebagai Materi Pembelajaran IPA-Biologi SMP Berbasis Potensi Lokal di Kawasan Pasir Pantai Depok Kabupaten Bantul. Prosiding Seminar Nasional. Malang 2015: FKIP UMM.

Sutartono. Pentingnya Literasi Informasi dalam Menyongsong MEA. Prosiding 
Seminar Nasional. 2015. Universitas Terbuka: Fakultas Ilmu Sosial dan Ilmu Politik.

Umam, K. Penerapan Media Digital dalam Pembelajaran Apresiasi Batik Kelas X SMA Negeri 1 Blega. Jurnal Pendidikan Seni Rupa. 2013. 1(1): 103104.

Utami, D. Information Literacy untuk Pembelajaran di Pendidikan Tinggi. Majalah Ilmiah Pembelajaran. 2007. 3(1): 83 .

Taufiq, M. Remediasi Miskonsepsi Mahasiswa Calon Guru Fisika pada Konsep Gaya Melalui Penerapan Model Siklus Belajar (Learning Cycle) 5E. Jurnal Pendidikan IPA Indonesia. 2012. 1(2): 201.

Yokhebed, Titin, dan Wahyuni, ES. Peningkatan Life Skill melalui Pembelajaran berbasis Keunggulan Lokal. Prosiding Seminar Nasional XIII Biologi 2016. Solo: FKIP UNS 